\title{
Utilization of Mineral Wool Waste and Waste Glass for Synthesis of Foam
}

\section{Glass at Low Temperature}

$\mathrm{Ru} \mathrm{Ji}^{\mathrm{a}}$, Yaxian Zheng ${ }^{\mathrm{a}}$, Zehui Zou ${ }^{\mathrm{a}}$, Ziwei Chen ${ }^{\mathrm{b}}$, Shen $\mathrm{Wei}^{\mathrm{c}}$, Xiaoyong Jinª ${ }^{\mathrm{a}}$, Mei Zhang ${ }^{\mathrm{a}}$.

${ }^{a}$ School of Civil and Resource Engineering, University of Science and Technology Beijing, 100083, Beijing, P.R. China

${ }^{\mathrm{b}}$ Department of Energy and Resources Engineering, College of Engineering, Peking University, 100871 Beijing, PR China

${ }^{\mathrm{c}}$ The Bartlett School of Construction and Project Management, University College London (UCL), 1-19 Torrington Place, London WC1E 7HB, United Kingdom *Corresponding author: zhangmei@ ustb.edu.cn

\section{Abstract}

To reduce the energy consumed by building part, a new method of producing foam glass at low temperature was proposed in this study. Mineral wool waste and waste glass recycled from building construction and demolition (C\&D) process were used as major raw materials. In the meanwhile, calcium carbonate $\left(\mathrm{CaCO}_{3}\right)$, borax $\left(\mathrm{Na}_{2} \mathrm{~B}_{4} \mathrm{O}_{7} \cdot 10 \mathrm{H}_{2} \mathrm{O}\right)$ and sodium phosphate $\left(\mathrm{Na}_{3} \mathrm{PO}_{4} \cdot 12 \mathrm{H}_{2} \mathrm{O}\right)$ were added as extra additives, which played the part of foamer, fluxing agent and foam stabilizer, respectively. The effects of different content of each additives and different sintering temperature on the properties of foam glass were investigated. Bulk density, cross-section view and microstructure of the specimens were showed. The experiment results showed that the optimal content of raw materials and additives was $40 \mathrm{wt} . \%$ mineral wool waste, $60 \mathrm{wt} . \%$ waste glass, $20 \mathrm{wt} . \%$ borax, 1-2 wt.\% calcium carbonate and 2 wt.\% sodium phosphate, and its optimal sintering temperature was $800^{\circ} \mathrm{C}$. The specimen sintered at this optimal condition had the most uniform foam structure and low bulk density of $0.7 \mathrm{~g} / \mathrm{cm}^{3}$. Finally, 
EnergyPlus ${ }^{\mathrm{TM}}$ was used to evaluate the benefit of applying this new foam glass on the reduction on space conditioning loads, especially in relatively colder zones.

\section{Keywords:}

Foam glass; thermal insulation material; solid waste; mineral wool waste, waste glass. 


\section{Introduction}

Building's life-cycle energy consumption, including construction and operation of buildings, approximately accounts for $47.5 \%$ of total primary energy consumption in China by 2014 [1][2]. In particular, the building operation sector consumption relating to heating and cooling systems accounts for over two thirds of building's life-cycle energy [2]. Air leakages and poor insulation of current buildings attribute to high energy consumption on space conditioning, corelating the increase in heating and cooling load [3][4]. Given that $15 \%$ of the thermal leakage is released through building envelope, researchers have attached great importance to lowering the thermal conductivity of the building envelope to reduce heat loss from the inner environment [3]. As a result, current policies reasonably require the retrofit for old buildings and efficient thermal insulation for new buildings [1]. Foam glass and ceramics now act as external wall thermal insulation materials due to their low thermal conductivities and densities [5-7]. Moreover, foam glass and ceramics have excellent sound absorption property and are incombustible compared with organic materials [7][8]. However, it is difficult to accomplish mass manufacturing of foam glass and ceramics with current producing technology and the preparation of foam ceramics accordingly costs more than that of organic materials [7]. Consequently, more economical and efficient ways to produce foam glass and ceramics must be proposed.

Now researchers have resorted to kinds of solid waste to produce ceramics [9-11]. Based on similar chemical composition, mineral wool waste, waste glass, high alumina fly ash and ceramic tile polishing waste, etc. are often chosen to make foam glass and ceramics. Polish researchers used hospital incineration ash together with borosilicate glass frit to produce glass-ceramic composites [9]. Some Chinese researchers resorted to lead-zinc mine tailings, fly ash and red mud as raw materials to prepare glass ceramic 
foams [10]. Besides, H.R. Fernandes et al. from University of Aveiro, Portugal, have studied the preparation of foams using sheet glass and fly ash as raw materials [11]. Therefore, it is feasible to use solid waste materials instead of mineral raw materials to prepare foam glass.

Mineral wool, covering a variety of inorganic materials such as rock wool, glass wool and slag wool, is widely used in building thermal insulation and accounts for $60 \%$ of total wall insulation product market [12]. By 1996, the annual yield of mineral wool had exceeded four hundred and fifty thousand tons in China. Mineral wool waste, generating mainly through this mineral wool manufacturing process and construction and demolition (C\&D) process, covers an important portion of domestic and worldwide solid waste. In order to reduce the amount of waste that legally and illegally sent to landfills, mineral wool waste should be recycled as much as possible. Currently, there are two primary methods for recycling mineral wool waste, including the reclamation of waste back into mineral wool manufacturing process and the use of it as a raw material in other products [13]. However, the recycling of mineral wool waste into manufacturing process is limited in two aspects. Firstly, it can lay difficulty in recycling waste from different sources due to the unknown composition and position of the disparate waste. Secondly, fine particles of mineral wool waste can clog feeding equipment. The binders used to solve this problem contains phenol and formaldehyde and thus can generate negative health effects [14]. A mass of researchers investigated the use of mineral wool waste as a raw material in other productions such as composite ceramics [15]. For example, Pranckeviceine $\mathrm{J}$ et al. [13] investigated the sintering characteristics of composite ceramics with low-melting illite clay and mineral wool waste as raw materials and nepheline syenite as addition. They found that with nepheline syenite, it is possible to alter the melting temperature and to change the length, density, water absorption, and 
burning shrinkage of this composite ceramics. Researchers from Lithuania [15] has used mineral wool production waste to replace the commercial microsilica additive in refractory concrete.

Waste glass is another important solid waste in China. According to statistics, the annual amount of waste glass weighs over 3.2 million tons and represents $2 \%$ of total municipal refuse in China [16]. Waste glass comes from multifarious societal aspects, including glass manufacturing, household waste, electronic products together with building construction and demolition process. In particular, as the number of glazed buildings continually increases recently, the amount of total C\&D glass waste increases. However, compared to developed countries, only $10 \%$ of glass waste is recycled in China which suggests that $90 \%$ of glass waste distributes disorderly. Regarding the imperishable property of glass, the discard of glass waste would become not merely a waste of glass resource but an occupation of land resource if it goes to the landfill [17]. Thus, more efficacious way to dispose glass waste should be researched for the accretion of reuse rate and the protection of the environment.

Given that mineral wool waste together with glass waste mainly contains $\mathrm{Al}_{2} \mathrm{O}_{3}$, $\mathrm{SiO}_{2}$ and $\mathrm{Na}_{2} \mathrm{O}$ which being similar to the chemical components of regular foam glass and ceramics [18], much of studies investigated the produce of ceramics with high $\mathrm{Al}_{2} \mathrm{O}_{3}$ and $\mathrm{SiO}_{2}$ content raw materials like mineral wool waste and waste glass [19-22]. $\mathrm{SiO}_{2}$ is usually used to make the generation of liquid phase during the sintering process of $\mathrm{Al}_{2} \mathrm{O}_{3}$ ceramics and thus lower the sintering temperature.

In this paper, mineral wool waste and glass waste were used as raw materials. At the same time, borax $\left(\mathrm{Na}_{2} \mathrm{~B}_{4} \mathrm{O}_{7} \cdot 10 \mathrm{H}_{2} \mathrm{O}\right)$, calcium carbonate $\left(\mathrm{CaCO}_{3}\right)$ and sodium phosphate $\left(\mathrm{Na}_{3} \mathrm{PO}_{4} \cdot 12 \mathrm{H}_{2} \mathrm{O}\right)$ were employed in small amounts as fluxing agent, foaming agent and foam stabilizer, respectively. Besides, this research formulates the mixed 
powder proportion in order to sinter at a lower temperature than previous studies. Macroscopic properties like bulk density and foams shape are showed and microscopic structure are also investigated. Moreover, EnergyPlus ${ }^{\mathrm{TM}}$, a common building energy simulation software is used for assessing this new foaming glass when applied as thermal insulation material for buildings.

\section{Experimental procedure}

\subsection{Raw materials}

Waste glass in this present study was recycled from municipal construction and demolition activity. Mineral wool waste was obtained from Shuozhou city, Shanxi Province, China. Chemical compositions of these two ingredients were analyzed and the result was shown in Table 1. The chemical constituents of waste glass appeared to be $\mathrm{SiO}_{2}$ and similar amount of $\mathrm{Al}_{2} \mathrm{O}_{3}$ while mineral wool waste contains $\mathrm{SiO}_{2}$ mainly. Besides, borax $\left(\mathrm{Na}_{2} \mathrm{~B}_{4} \mathrm{O}_{7} \cdot 10 \mathrm{H}_{2} \mathrm{O}\right)$ was added in order to lower the softening temperature $[23,24]$. Tri-sodium phosphate dodecaphydrate $\left(\mathrm{Na}_{3} \mathrm{PO}_{4} \cdot 12 \mathrm{H}_{2} \mathrm{O}\right)$ powder was also used as an additive to help soften at a lower temperature and in the mean while stabilize the foams $[25,26]$. Finally, calcium carbonate was chosen as foaming agent to generate $\mathrm{CO}_{2}$ gas by oxidation decomposition reaction [27]. Here, oxygen required here is available through the atmosphere in the furnace [28]. Then, cavities which benefit the thermal insulation would be created in the liquefied glass by $\mathrm{CO}_{2}$ gas.

Table 1. The chemical compositions (wt.\%) of raw materials.

\begin{tabular}{lllllllllll}
\hline Raw materials & $\mathrm{SiO}_{2}$ & $\mathrm{Al}_{2} \mathrm{O}_{3}$ & $\mathrm{~K}_{2} \mathrm{O}$ & $\mathrm{Na}_{2} \mathrm{O}$ & $\mathrm{Fe}_{2} \mathrm{O}_{3}$ & $\mathrm{TiO}_{2}$ & $\mathrm{CaO}$ & $\mathrm{MgO}$ & $\mathrm{SO}_{3}$ & LOI \\
\hline Waste glass & 72.23 & 1.07 & 0.56 & 8.20 & 0.36 & 0.04 & 13.94 & 2.92 & 0.30 & 0.19 \\
Mineral wool waste & 51.54 & 42.93 & 0.24 & 0.07 & 1.28 & 0.97 & 0.57 & 0.14 & 0.00 & 1.90 \\
\hline \multicolumn{2}{l}{ * LOI (loss on ignition) } \\
\multicolumn{2}{l}{} & & & & & & & &
\end{tabular}




\subsection{Sample preparation}

It is already been proved that the selection of sintering temperature affects the frothing result significantly. Many preceded studies have discussed the chosen of sintering temperature in different cases. Particularly, in this case, a properly low sintering temperature and a maximum utilization of mineral wool waste are about to be decided. Thus, according to the above purposes, the phase diagram of $\mathrm{Na}_{2} \mathrm{O}-\mathrm{Al}_{2} \mathrm{O}_{3}-\mathrm{SiO}_{2}$ and $\mathrm{Na}_{2} \mathrm{O}-\mathrm{CaO}-\mathrm{SiO}_{2}-\mathrm{MgO}-\mathrm{Al}_{2} \mathrm{O}_{3}$ was employed and it appears that the proportions of wool waste and glass would affect the eutectic temperature. Also, the additives will contribute to the change of eutectic temperature. Consequently, the proportions of raw materials and additives should be adjusted properly.

Table 2. Raw materials compositions(wt.\%) of samples.

\begin{tabular}{lllll}
\hline Sample & Mineral wool waste & Waste glass & Borax & Calcium carbonate \\
\hline S1 & 100 & 0 & 20 & 1 \\
S2 & 80 & 20 & 20 & 1 \\
S3 & 60 & 40 & 20 & 1 \\
S4 & 40 & 60 & 20 & 1 \\
S5 & 20 & 80 & 20 & 1 \\
\hline
\end{tabular}

Table 3. Chemical compositions(wt.\%) of samples.

\begin{tabular}{lllllllllll}
\hline Sample & $\mathrm{SiO}_{2}$ & $\mathrm{Al}_{2} \mathrm{O}_{3}$ & $\mathrm{~K}_{2} \mathrm{O}$ & $\mathrm{Na}_{2} \mathrm{O}$ & $\mathrm{Fe}_{2} \mathrm{O}_{3}$ & $\mathrm{TiO}_{2}$ & $\mathrm{CaO}$ & $\mathrm{MgO}$ & $\mathrm{SO}_{3}$ & $\mathrm{LOI}$ \\
\hline $\mathrm{S} 1$ & 72.23 & 1.07 & 0.56 & 8.2 & 0.36 & 0.04 & 13.94 & 2.92 & 0.3 & 0.19 \\
$\mathrm{~S} 2$ & 68.092 & 9.442 & 0.496 & 6.574 & 0.544 & 0.226 & 11.266 & 2.364 & 0.24 & 0.532 \\
$\mathrm{~S} 3$ & 63.954 & 17.814 & 0.432 & 4.948 & 0.728 & 0.412 & 8.592 & 1.808 & 0.18 & 0.874 \\
$\mathrm{~S} 4$ & 59.816 & 26.186 & 0.368 & 3.322 & 0.912 & 0.598 & 5.918 & 1.252 & 0.12 & 1.216 \\
$\mathrm{~S} 5$ & 55.678 & 34.558 & 0.304 & 1.696 & 1.096 & 0.784 & 3.244 & 0.696 & 0.06 & 1.558 \\
\hline
\end{tabular}

According to the possibly suited range of compositions suggested in the phase diagrams, ingredients were mixed in different proportions to determine the best weight ration. The ingredients compositions of samples and the chemical compositions of samples were shown in Table 2 and 3, respectively. Mineral wool waste and waste glass 
were mixed in different mass ratios from 10:0 to 2:8 named as $\mathrm{S} 1$ to $\mathrm{S} 5$. The raw materials were first crushed and then were ground in mill jars with a planetary ball mill for 8 hours. A pressure of $15 \mathrm{MPa}$ was added to powder mixtures of each sample using a mould afterwards. The samples thus were made into disks with a diameter of $22 \mathrm{~mm}$ and thickness of $10 \mathrm{~mm}$.

The disk samples were heated to $500^{\circ} \mathrm{C}$ for $40 \mathrm{~min}$ and kept at $500^{\circ} \mathrm{C}$ for $20 \mathrm{~min}$ in a muffle furnace in order to remove water trapped in the samples and prevent samples from fracturing caused by lopsided heating. Afterwards, samples were heated to respective peak temperature ranging from 600 to $800^{\circ} \mathrm{C}$ basically at a rate of $20^{\circ} \mathrm{C} / \mathrm{min}$ and were kept at peak temperature for another $20 \mathrm{~min}$, then naturally cooled to room temperature.

Bulk density of materials was determined either by Archimedes method or directly by measuring the weight and the external sizes of the sintered samples. Microstructure observations of internal pores of foam glass were analyzed using Scanning electron microscope (SEM, S-4800, Hitachi).

\section{Results and discussion}

\subsection{Effect of mineral wool waste content}

To study the effect of mineral wool waste content, bulk density trend and top view of sample S0 to S5 were displayed in Fig.1. These samples were sintered at $800{ }^{\circ} \mathrm{C}$ and all had $20 \mathrm{wt} . \%$ borax, $1 \mathrm{wt} . \%$ foaming agent and $2 \mathrm{wt} . \%$ sodium phosphate. The S0 in Fig.1(b) is the green sample before sintering and this sample has a bulk density of 1.3 $\mathrm{g} / \mathrm{cm}^{3}$. Fig.1(b) shows that from S1 to S5, sample volume first decreases then increases. Meanwhile, it can be seen from Fig.1(a) that bulk density increases from $1.50 \mathrm{~g} / \mathrm{cm}^{3}$ to $2.18 \mathrm{~g} / \mathrm{cm}^{3}$ following the decrease in content of mineral wool waste from S1 to S3. Then 
a decline of bulk density from $2.18 \mathrm{~g} / \mathrm{cm}^{3}$ to $0.43 \mathrm{~g} / \mathrm{cm}^{3}$ can be seen from sample $\mathrm{S} 3$ to S5. This evolution can be explained as follow.

(a)

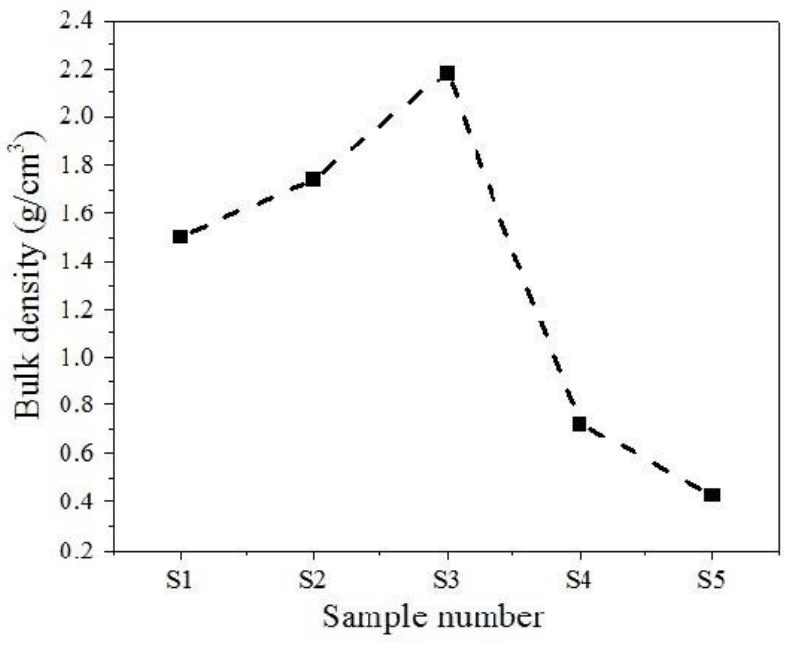

(b)

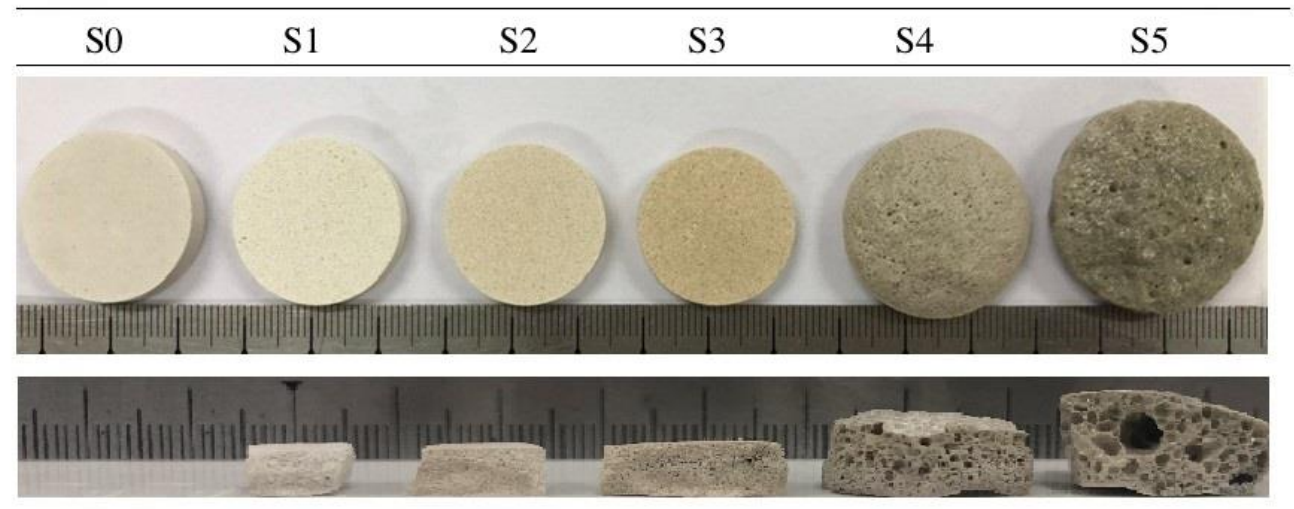

Fig.1. Effects of the content of mineral wool waste on the (a) bulk density,(b) top and side view of green sample S0 and sample S1 S2 S3 S4 S5 at $800^{\circ} \mathrm{C}$.

For sample $\mathrm{S} 1$ to $\mathrm{S} 3$, the previous rise in bulk density is because that samples with more mineral wool waste have more $\mathrm{Al}_{2} \mathrm{O}_{3}$ than $\mathrm{SiO}_{2}$ content and differ more from the eutectic point in ternary diagram of $\mathrm{CaO}, \mathrm{Al}_{2} \mathrm{O}_{3}$ and $\mathrm{SiO}_{2}$ system [29-30]. Consequently, S3 has the lowest softening temperature. This could result in the increase liquefaction from $\mathrm{S} 1$ to $\mathrm{S} 3$ at a certain sintering temperature. Increasing liquefaction resulted in the denser base of samples. Thus, S3 has the peak bulk density and the smallest volume among S1 to S3, which can be seen from Fig.1(b). Besides, because of the liquefaction, all S1, S2, S3 has higher bulk density and smaller volume than the green sample S0. 
For sample S4 to S5, when the content ratio of mineral wool waste and waste glass rises to 4:6 and 2:8 liquefaction were further intensified. Better liquefaction in the body could help the maintaining of cavities generated by $\mathrm{CO}_{2}$ gas. As a consequence, samples S4 and S5 have bigger volumes and lower bulk densities. We can also infer from the decrease of bulk density from S4 to S5 that a good deal of liquid could also prevent pores from escaping.

Moreover, from Fig.1 (b), it can be found that S4 has more glossier appearance and uniform pore distribution than S5 and it has less escaped pores on its appearance. Thus, the content of mineral wool waste of S4 (40 wt.\%) was chosen to fulfill next experiments.

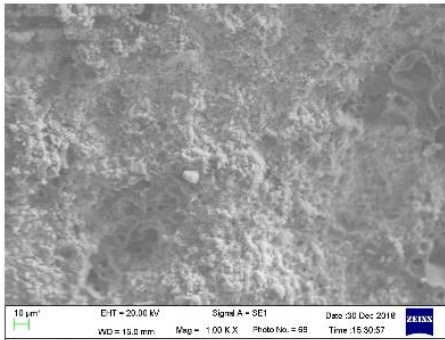

(a)

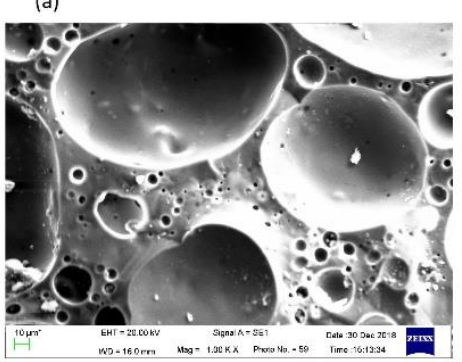

(d)

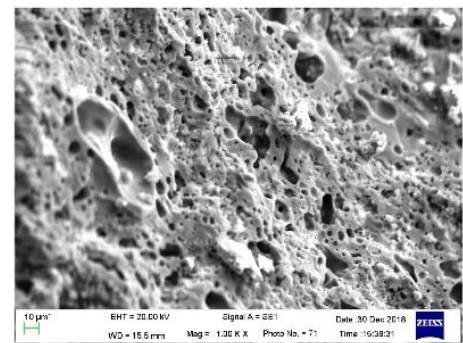

(b)

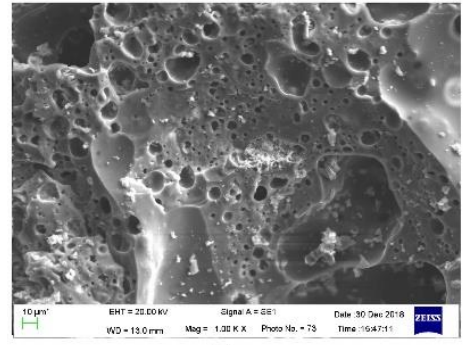

(c)

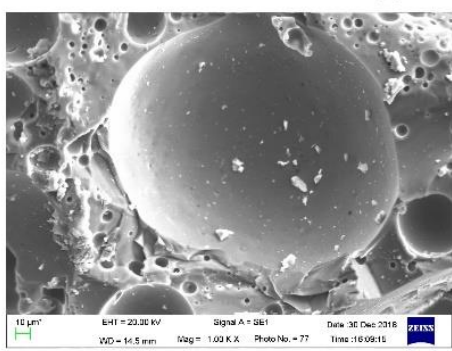

Fig.2. SEM images of samples S1 S5 sintered at $800{ }^{\circ} \mathrm{C}$.

Furthermore, SEM images of samples S1 S5 sintered at $800{ }^{\circ} \mathrm{C}$ were showed in Fig.2. These images indicate that from sample $\mathrm{S} 1$ to $\mathrm{S} 5$, there is a higher sintering degree of sample matrix. In addition, with the increase of waste glass (from S1 to S5), cavities generate and become larger. It can be concluded that the addition of waste glass promotes sample matrix densification and cavities generation. 


\subsection{Effect of sintering temperature}

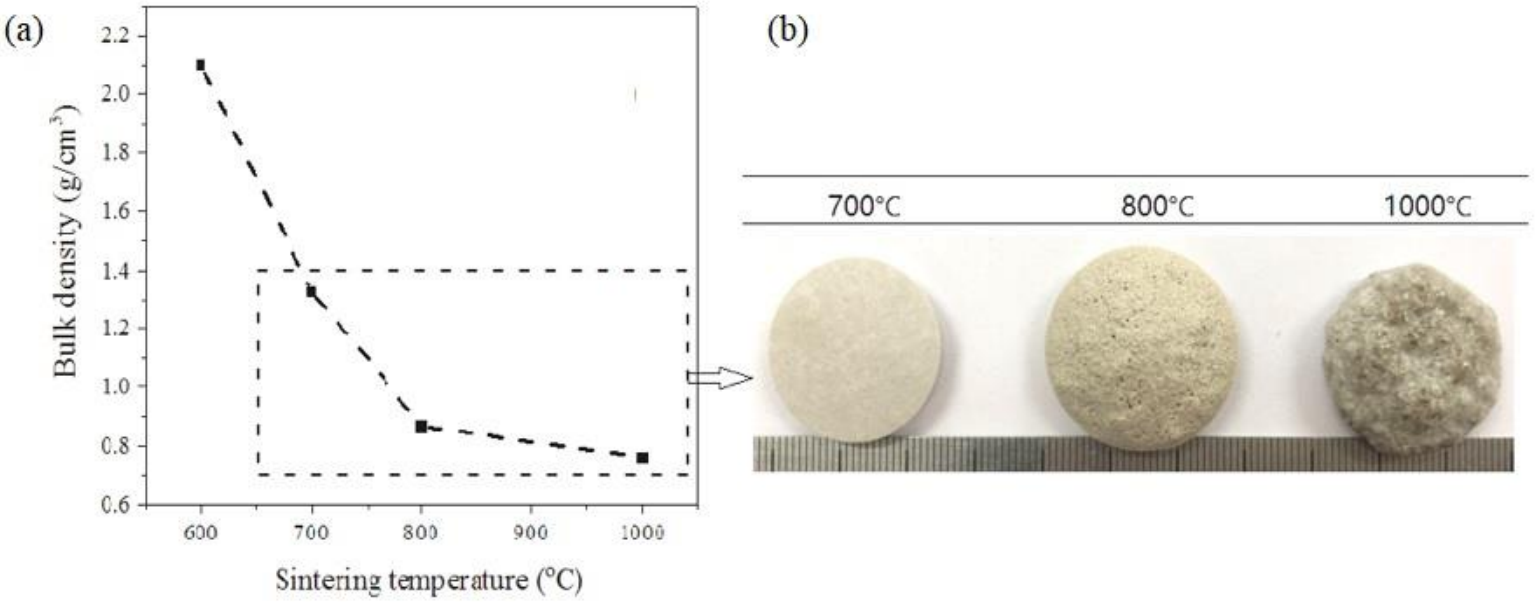

Fig.3. Effects of sintering temperature on the (a) bulk density, (b) top view of sample S4.

The effects of sintering temperature on sample S4 were investigated. The results which include bulk density and top views of samples were shown in Fig.3. It can be seen from the picture that the densities of samples decrease at different rates as the sintering temperatures increased. The sample sintered at $600^{\circ} \mathrm{C}$ has the maximum density of 2.10 $\mathrm{g} / \mathrm{cm}^{3}$. The density of sample sintered at $700^{\circ} \mathrm{C}$ decreases sharply to $1.33 \mathrm{~g} / \mathrm{cm}^{3}$. Then bulk density of sample relatively largely decreases to $0.87 \mathrm{~g} / \mathrm{cm}^{3}$ when sintered at $800{ }^{\circ} \mathrm{C}$ and slightly decreases to $0.76 \mathrm{~g} / \mathrm{cm}^{3}$ when sintered at $1000{ }^{\circ} \mathrm{C}$. This pattern can be explained as follow.

It can be inferred that an increase in bulk density would exsist at sintering temperature below $600^{\circ} \mathrm{C}$. This is because the increasing sintering temperautres would help the liquidation in the body and thus the body compacts which leads to the increasing bulk density. When the sintering temperature reaches $700^{\circ} \mathrm{C}$, the foaming agent began to decomposed and $\mathrm{CO}_{2}$ gas generated. Enough generated gas was kept in the body by 
the softening glass and thus the cavities lowered the density of the sample significantly. Similar process existed at $800^{\circ} \mathrm{C}$. The intensified liquid phase generation accelerated the liquidation and the densification, but the calcium carbonate decomposition constantly resulted in the increase in the volume of samples and the liquid phase laso helped the maintaining of cavaties. This pattern can be seen in the Fig.3(b). When the sintering temperature reaches $1000{ }^{\circ} \mathrm{C}$, the liquid phase and $\mathrm{CO}_{2}$ gas generation continuely accelerated. However, lots of small pores coalesced into larger pores and $\mathrm{CO}_{2}$ gas escaped from the body, which would lead to the collapse of sample. Consequently, specimen sintered at $1000^{\circ} \mathrm{C}$ has a more asperous surface as shown in Fig.3(b), and processes occurred at $1000^{\circ} \mathrm{C}$ contributed to the slight decrease in bulk density.

In order to explain this phenomenon, SEM images of sample $\mathrm{S} 4$ sintered at different temperature were showed in Fig.4. First, it can be observed that there is a relatively granular structure $\left(600^{\circ} \mathrm{C}\right)$. Then, with the increase of the sintering temperature $\left(700^{\circ} \mathrm{C}\right)$, there is partial sintering and cavities in the body of sample, indicating a higher degree of sintering and maintaining of gas. At $800^{\circ} \mathrm{C}$ and $1000^{\circ} \mathrm{C}$, the fracture surface of sample S4 becomes more and more smooth, and cavities become larger. It can be concluded that the increase of the sintering temperature can elevate the matrix densification and the generation of cavities, which is consistent with the phenomenon in Fig.3. 


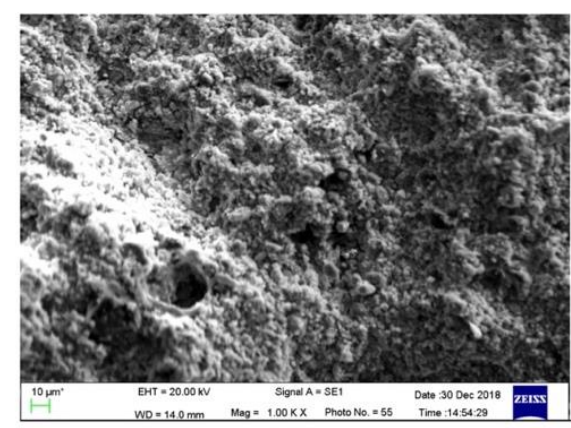

(a)

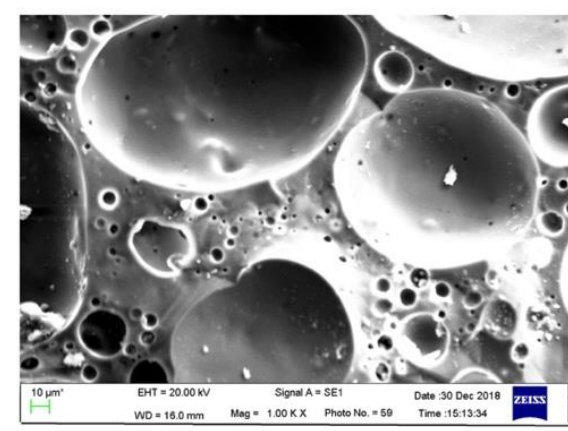

(c)

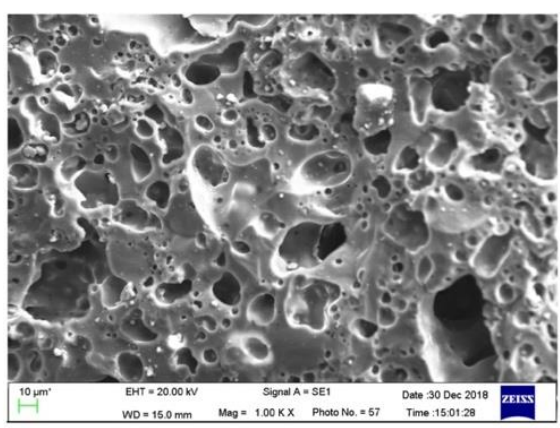

(b)

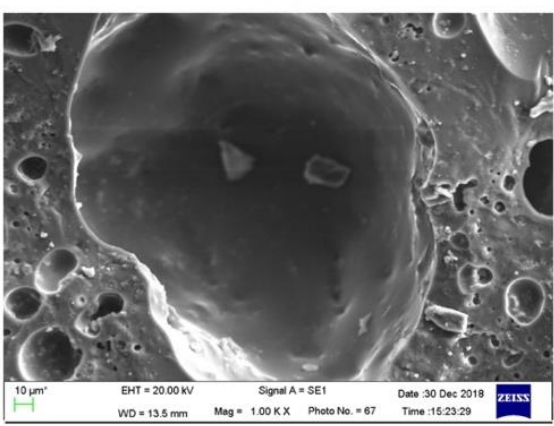

(d)

Fig.4. The SEM images of samples ultimately sintered at different temperature:

(a) $600{ }^{\circ} \mathrm{C}$, (b) $700{ }^{\circ} \mathrm{C}$, (c) $800{ }^{\circ} \mathrm{C}$, (d) $1000{ }^{\circ} \mathrm{C}$.

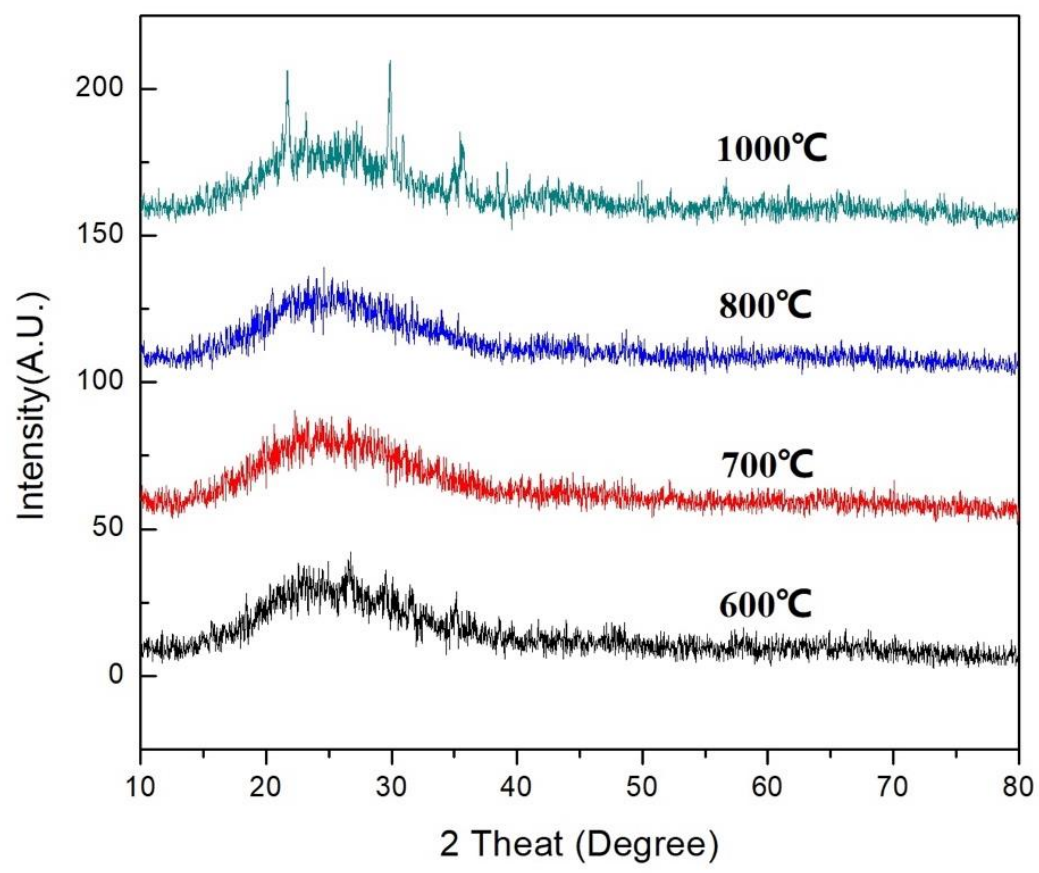

Fig.5. XRD analysis of samples $\mathrm{S} 4$ sintered at different temperatures. 
Moreover, XRD analysis of samples S4 sintered at different temperatures were carried out to look at the crystal phase composition of the sintered sample. This test indicates that sintered sample below $1000{ }^{\circ} \mathrm{C}$ are amorphous, while for the sample sintered at $1000{ }^{\circ} \mathrm{C}$ there is also anorthite generation.

In conclusion, the samples sintered at $800^{\circ} \mathrm{C}$ and $1000^{\circ} \mathrm{C}$ have the lowest densities. However, the sample sintered at $800^{\circ} \mathrm{C}$ has a brighter and more glazed appearance than the sample sintered at $1000{ }^{\circ} \mathrm{C}$. Besides, the sample sintered at $800{ }^{\circ} \mathrm{C}$ has more unanimous pores which benefits the compressive strength. Thus, temperature of $800^{\circ} \mathrm{C}$ was chosen accordingly as the sintering temperature in the following study.

\subsection{Effect of borax content}
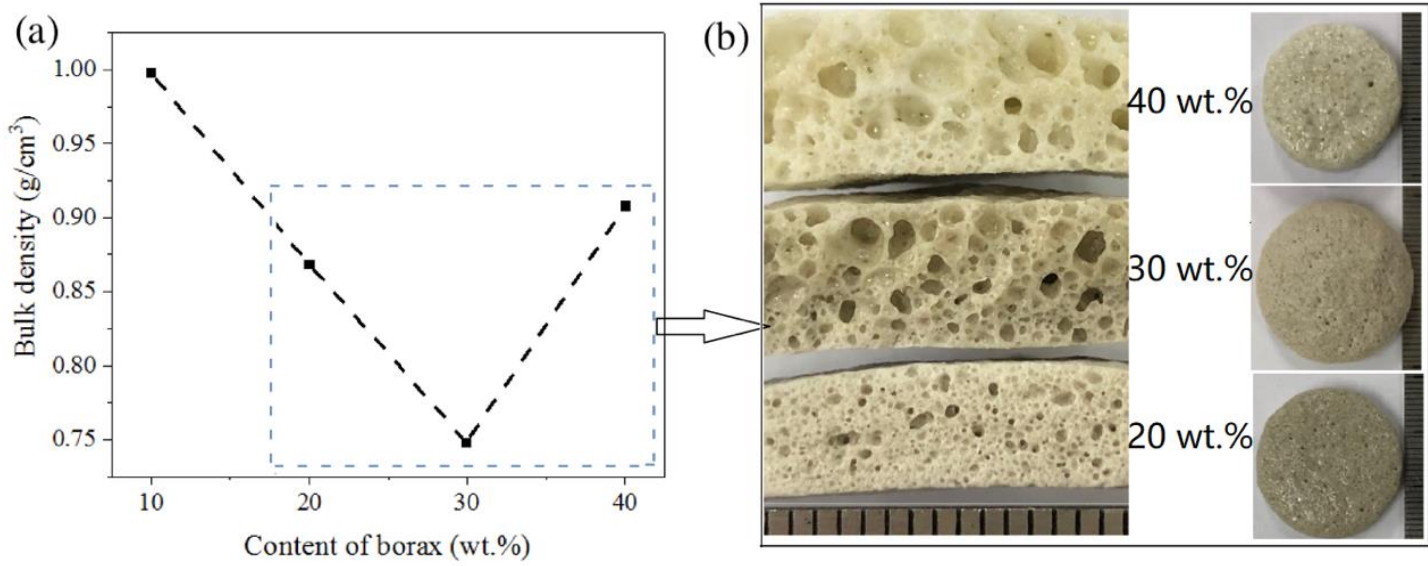

Fig.6. Effect of borax content on (a) bulk density and (b)top and side views of samples containing $40 \mathrm{wt} . \%$ mineral wool waste(S4) sintered at $800^{\circ} \mathrm{C}$.

Fig. 6 revealed the evolution of bulk density of $\mathrm{S} 4$ sintered at $800{ }^{\circ} \mathrm{C}$ with increasing amount of borax $\left(\mathrm{Na}_{2} \mathrm{~B}_{4} \mathrm{O}_{7} \cdot 10 \mathrm{H}_{2} \mathrm{O}\right)$ addition from 10 to $40 \mathrm{wt}$.\%. Borax was added as fluxing agent to lower the softening temperature as its composition of sodium. It can be seen from Fig.6(a) that the samples containing $10 \mathrm{wt} \%$ borax have the highest bulk densities, which is $1.0 \mathrm{~g} / \mathrm{cm}^{3}$. When the content reaches to $20 \mathrm{wt} . \%$, the densities 
decrease to $0.86 \mathrm{~g} / \mathrm{cm}^{3}$. This is followed by a relatively slow decrease in bulk densities of sample. Then a large increase in bulk density appears as the addition of borax reaches $40 \mathrm{wt} . \%$. This pattern could be explained as follow.

With increasing borax content, liquid phase generation was promoted which helped to retain $\mathrm{CO}_{2}$ gas. Thus, bulk densities decrease at previous stage. However, when the content of sodium exceeds a certain point, liquidation continually intensified and $\mathrm{CO}_{2}$ gas was able to escape from body leaving a number of open pores on the surface of samples, which can be seen in Fig.6(b). Also, some small pores in the bodies combined into larger pores and larger pores tend to exsist on the top of the bodies. These processes result in the increase in bulk densities of samples with more content of borax. Thus, these processes could explain the increasing density of sample with $40 \mathrm{wt}$.\% borax.

\subsection{Effect of foaming agent content}
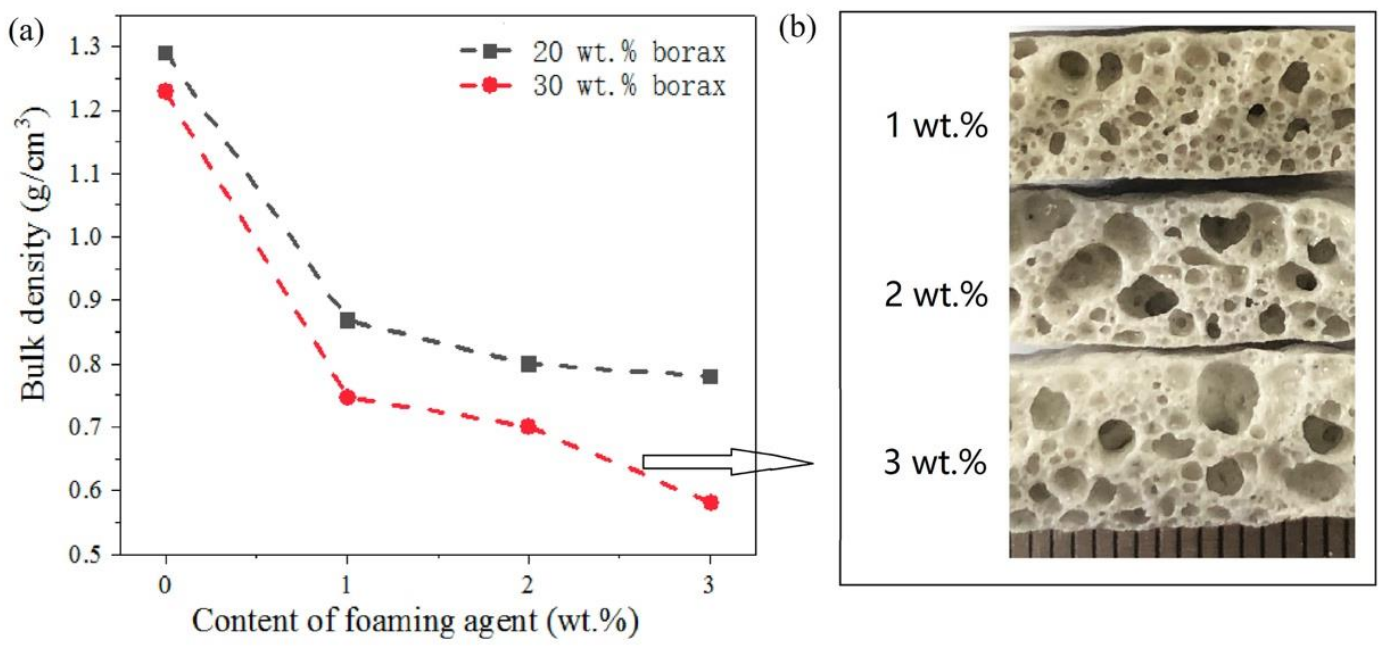

Fig.7. Effects of content of foaming agent on the (a) density of sample S4, (b)

side views of samples containing $30 \mathrm{wt} \%$ borax with $1 \mathrm{wt} . \%$ to $3 \mathrm{wt} . \%$ foaming agent

$$
\text { sintered at } 800^{\circ} \mathrm{C} \text {. }
$$

Fig.7 presents the effect of foaming agent on bulk density. As shown in Fig.7, to samples containing $20 \mathrm{wt} . \%$ borax, bulk density has a maximum value of $1.29 \mathrm{~g} / \mathrm{cm}^{3}$ when sintered without foaming agent. However, bulk density decreases sharply to 0.86 
$\mathrm{g} / \mathrm{cm}^{3}$ when added $1 \mathrm{wt} . \%$ foaming agent. With the increasing addition of foaming agent from 2 wt. $\%$ to 3 wt. $\%$, bulk density decreases slowly to $0.8 \mathrm{~g} / \mathrm{cm}^{3}$ and then to 0.78 $\mathrm{g} / \mathrm{cm}^{3}$, respectively. To samples containing $30 \mathrm{wt} . \%$ borax, the bulk density decreases slightly from $0.75 \mathrm{~g} / \mathrm{cm}^{3}$ to $0.70 \mathrm{~g} / \mathrm{cm}^{3}$ with the increasing content of foaming agent from 1 wt.\% to 2 wt.\% and it is followed by a largely lower bulk density of sample with 3 wt.\%.

The above pattern can be explained as follow. When only $1 \mathrm{wt} . \%$ foaming agent was added to the sample, it brought about $\mathrm{CO}_{2}$ gas generation, resulting in a significant decrease in bulk density of sample. However, with the increasing amount of foaming agent, gas pressure continually increases and outweighs strength of pore walls leading to cracks and open pores in the surface. So with more than $2 \mathrm{wt} . \%$ foaming agent added to samples containing 20 and $30 \mathrm{wt} . \%$ borax, more pores would come into being and small adjacent pores tend to combine into larger pores. For example, Fig.7(b) shows the evolution of side views of the specimen with $30 \mathrm{wt} . \%$ borax. The trend that larger pores came into being, which is mentioned above, could be identified easily.

On the basis of above discussion and the performance of bulk density and the side views, the suitable content of foaming agent is $1 \mathrm{wt} . \%$ and $2 \mathrm{wt} . \%$. 


\subsection{Effect of sodium phosphate}

(a)

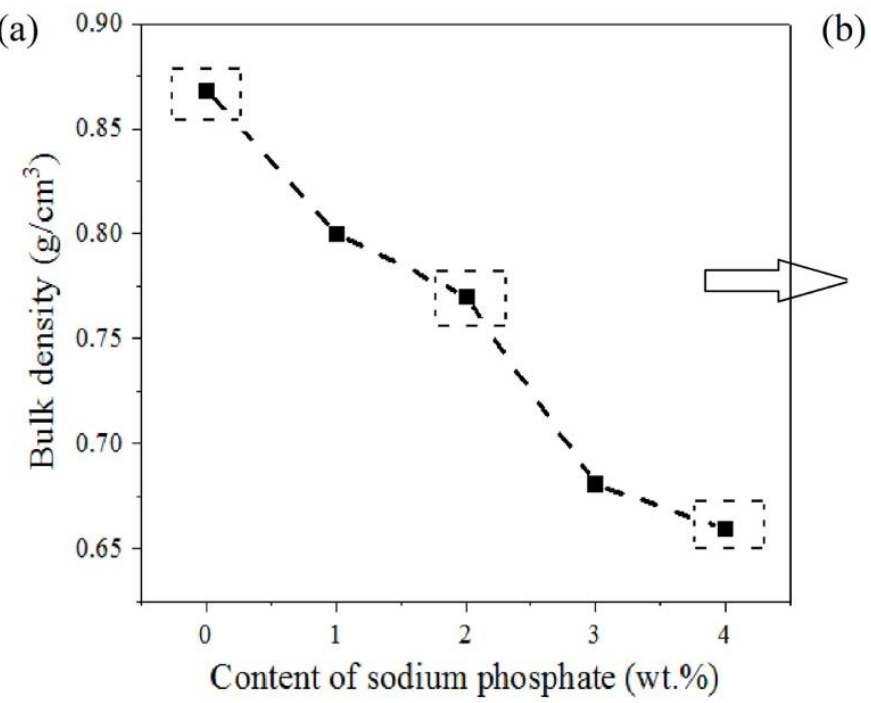

(b)

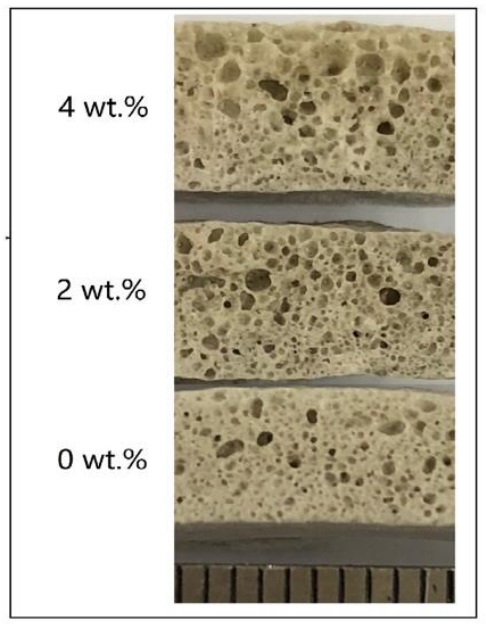

Fig.8. The effect of $\mathrm{Na}_{3} \mathrm{PO}_{4} \cdot 12 \mathrm{H}_{2} \mathrm{O}$ content on the (a) bulk density,(b) side views of S4 with $20 \mathrm{wt} . \%$ borax, $1 \mathrm{wt} . \%$ foaming agent sintered at $800^{\circ} \mathrm{C}$.

Sodium phosphate was added as another addition to samples in order to stabilize the pore structure and improve uniformity of pores based on one of its decomposition procduct of $\mathrm{P}_{2} \mathrm{O}_{5}$. More unanimous pores would augment samples' compressive strength. Besides, sodium phosphate would intensify the liquidation and lower the sintering temperature because of its another decomposition procduct of $\mathrm{Na}_{2} \mathrm{O}$. In order to further understand effects of sodium phosphate, different amounts of sodium phosphate (from 0 to $4 \mathrm{wt} . \%$ ) were added to the sample S4 with $20 \mathrm{wt} . \%$ borax, $1 \mathrm{wt} . \%$ foaming agent, and the sample was sintered at $800^{\circ} \mathrm{C}$. Results are showed in Fig. 8 .

It can be seen from Fig.8. that the density of samples keep declining with the increase of content of $\mathrm{Na}_{3} \mathrm{PO}_{4} \cdot 12 \mathrm{H}_{2} \mathrm{O}$. Two relatively large decreases in bulk density exsist in 1 wt. $\%$ and 3 wt. $\%$ of sodium phosphate, which are $0.80 \mathrm{~g} / \mathrm{cm}^{3}$ and $0.68 \mathrm{~g} / \mathrm{cm}^{3}$, respectively. It can be inferred from the density trend that more liquid generation was brought about by the increasing amount of sodium phosphate. More liquid phase would 
encourage pore retention and prevent gas from escaping. Thus, the density of samples continually decrease at sintering temperature of $800{ }^{\circ} \mathrm{C}$.

$\mathrm{Na}_{3} \mathrm{PO}_{4} \cdot 12 \mathrm{H}_{2} \mathrm{O}$ could act more as a foam stablilizer than a fluxing agent at high sintering temperatures. Fig.8(b) shows the side views of samples with disparate amount of $\mathrm{Na}_{3} \mathrm{PO}_{4} \cdot 12 \mathrm{H}_{2} \mathrm{O}$ in order to investigate the role of phosphorus at a relatively high sintering temperature of $800{ }^{\circ} \mathrm{C}$. It can be seen from the side views that when the content of sodium phosphate increased from $0 \mathrm{wt} . \%$ to $2 \mathrm{wt} . \%$, the size of cavities in the sample became unanimous. But with the increasing content of sodium phosphate, the small pores tend to form bigger pores and were kept on the top of samples.

\subsection{Energy conservation evaluation}

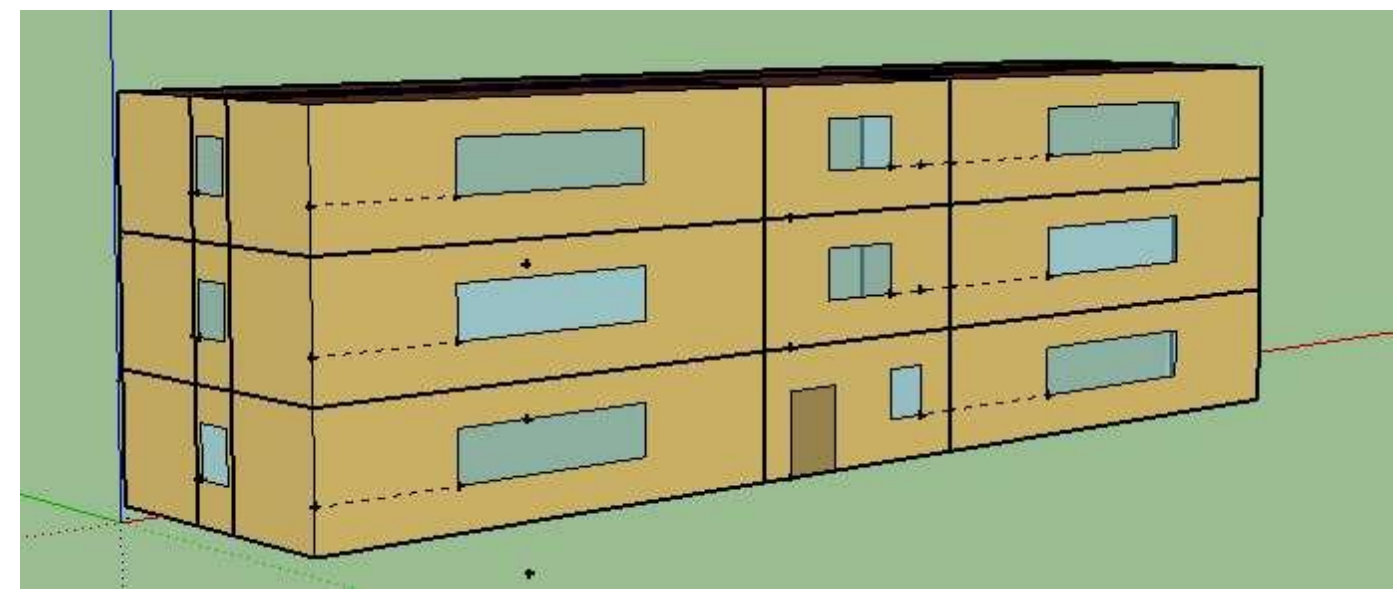

Fig. 9. The building simulation model.

As aforementioned, the application of foam glass will reduce buidling operation energy consumption by lowering the space heating and cooling loads. In order to testify this new insulation material utility detailedly, we use EnergyPlus ${ }^{\mathrm{TM}}$ to simulate the running conditions. EnergyPlus ${ }^{\mathrm{TM}}$ is a common and powerful building energy simulation software and is often used to assess the performance of building materials [31]. Its reliability on modelling has been validated by many researches. It uses heat balance method and conduction transfer function algorithm to approach this case. 
As shown in Fig. 9, the building that we use in this simultion model has 3 stories and covers an area of 666 square meters. The traditional construction of exterior wall acting as control group has three layers which are $25 \mathrm{~mm}$ cement mortar, $200 \mathrm{~mm}$ reinforced concrete and $20 \mathrm{~mm}$ composite mortar. The three layers have different thermal conductivity which is $0.97 \mathrm{~W} /(\mathrm{m} \cdot \mathrm{K}), 1.74 \mathrm{~W} /(\mathrm{m} \cdot \mathrm{K})$ and $0.65 \mathrm{~W} /(\mathrm{m} \cdot \mathrm{K})$, respectively. In comparison, our exterior wall replaces the middle layer in traditional construction with foam glass proposed previously and the rest two layers remain the same. This new layer has a thermal conductivity of $0.36 \mathrm{~W} /(\mathrm{m} \cdot \mathrm{K})$ which is tested in lab.

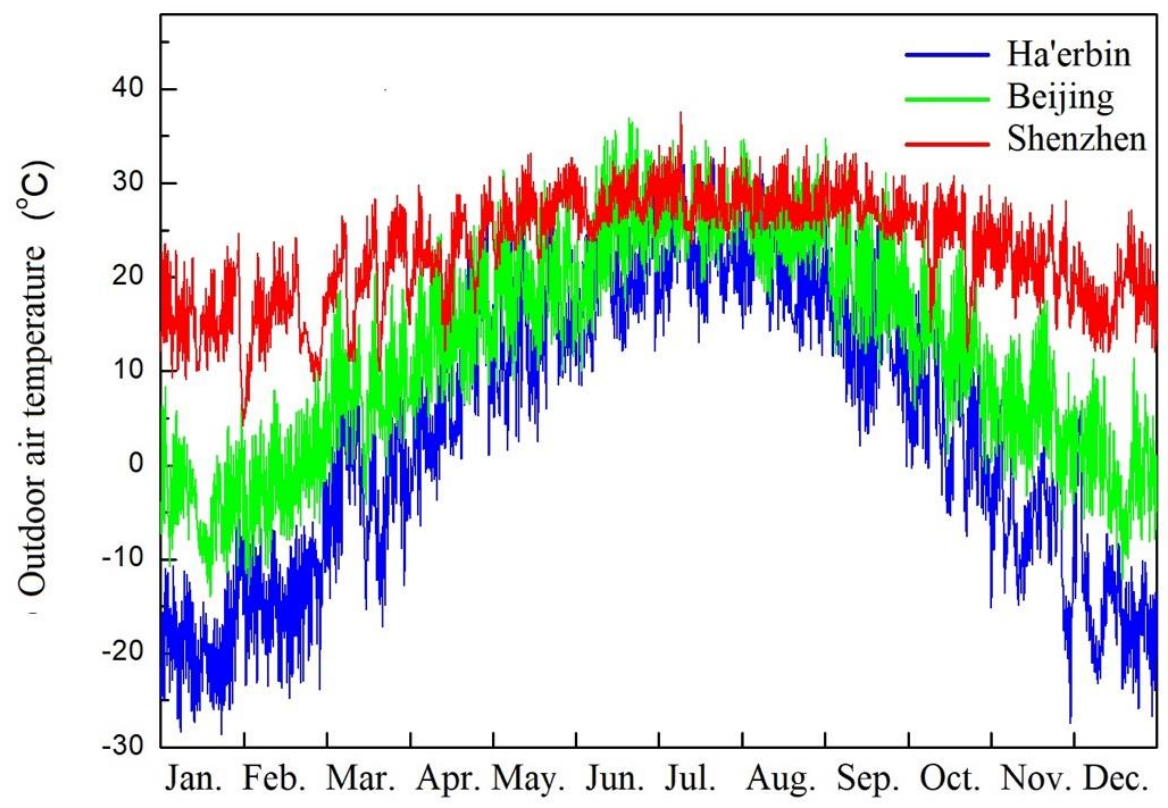

Fig.10. Outdoor air temperature in three climates.

According to Chinese architectural thermal design division, there are five climate districts in China and we choose three typical zones: severe cold zone, cold zone and hot summer \& warm winter zone in this simulation, due to their largely difference in climate features (Fig.10), and then Ha'erbin, Beijing and Shenzhen are chosen as the 
representitive cities, respectively. For this model, the surfaces of walls and roof were exposed to outdoor environment.

Then, in this research, ideal HVAC system was applied in this simulation model, which keep the indoor air temperature in a comfort temperature range. Here, the HVAC system was set to provide cooling air when the room air temperature is higher than 26 ${ }^{\circ} \mathrm{C}$, while when the room air temperature is lower than $18{ }^{\circ} \mathrm{C}$ the HVAC system begins to supply heating air.
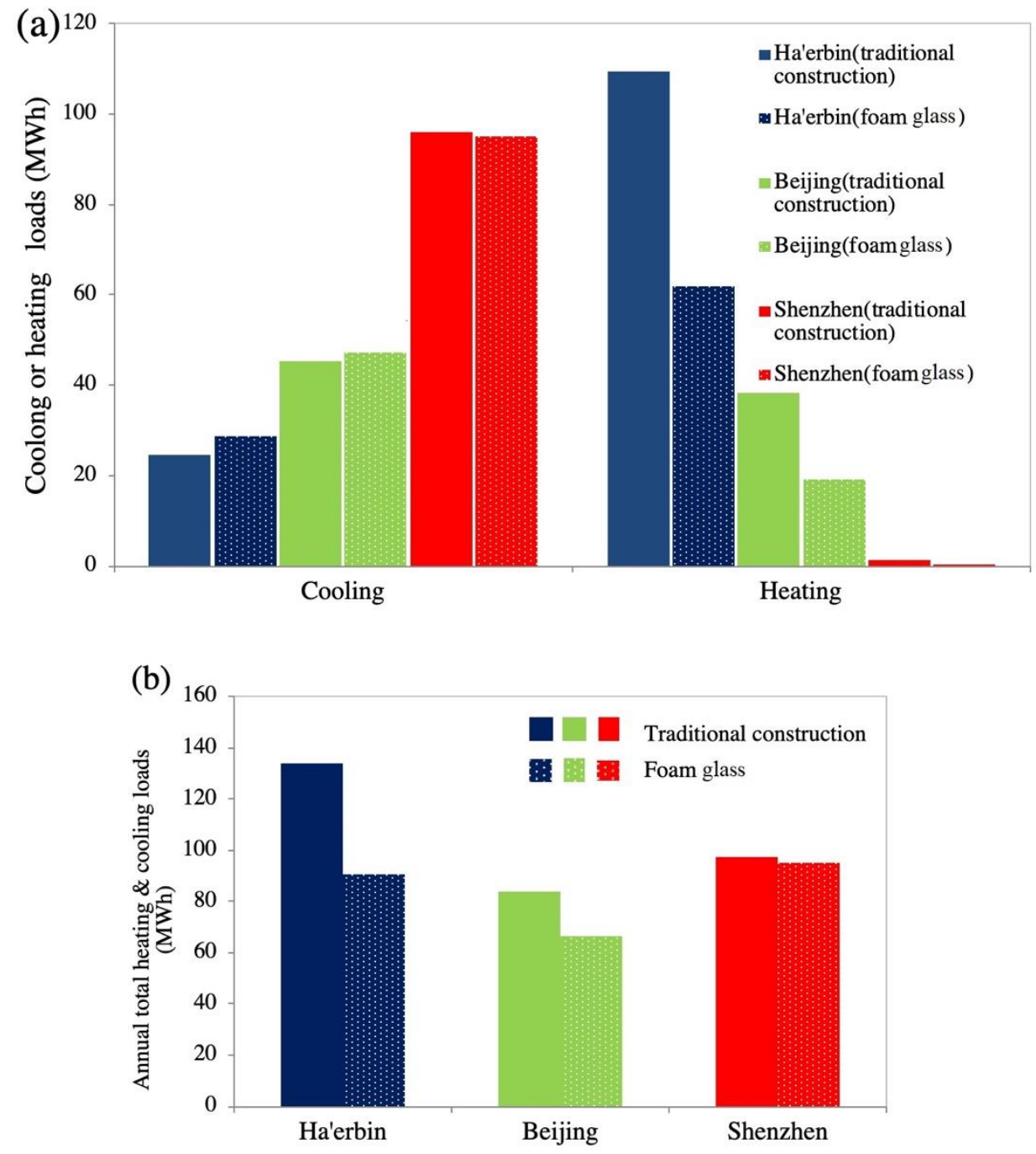

Fig.11. Heating and cooling loads in different climate regions for different exterior walls: (a) separate district loads and (b) annual loads 
Fig. 11 shows the result of the building energy consumption simulation. Separate district heating and cooling loads together with the annual loads of different cities and different constructions are displayed. From Fig. 8(a), it can be seen that the application of foam glass reduce the heating load efficiently, which is $43.3 \%, 50.2 \%, 78.9 \%$, respectively. As for cooling load, the application of foam glass causes a spot of increase in Ha'erbin (severe cold zone) and Beijing (cold zone) in summer, while a spot of decrease in Shenzhen. It can be explained as that, during winter, there is a significant temperature difference in colder zones and foam glass lowers the heat transfer through the exterior wall efficiently. However, in summer, the temperature difference between design day (set in the simulation) and the indoor environment is smaller and a great portion of cooling load generates indoors, which may cause the a slightly increase in cooling load.

Fig.11(b) shows the annual heating \& cooling loads combining the heating and cooling part. It can be seen from the bars that the application in all three cities could reduces the annual loads especially in Ha'erbin, and the reduction percent is $32.2 \%$, $20.6 \%, 1.9 \%$ in Ha'erbin, Beijing and Shenzhen, respectively. It could be inferred that the foam glass has greater utility on lowering the heating load. Besides, the energy consumed by heating part covers an increasing amount in the annual consumption with the distrct getting colder. In this case, the energy consumption saved in Ha'erbin is 43.1 MWh which is equivalent to $5307.38 \mathrm{~kg}$ of standard coal anually only in $666 \mathrm{~m}^{2}$. Thus, if this foam glass wall insulation could be applied in northern China (colder zones), the energy conservation would be remarkeble.

\section{Conclusion}

This study suggested the feasibility of using mineral wool waste and waste glass as raw materials to produce foam glass which mainly came from C\&D process. 
The result of macroscopic properties and microstructure suggested that with the decrease of mineral wool waste content and the increase of sintering temperature, more liquid phase generated and the foaming of samples thus benefited. The result showed that the optimal mineral wool waste content is $40 \mathrm{wt} . \%$, while the sintering temperature is $800^{\circ} \mathrm{C}$.

Furthermore, borax, as one of the additions, lowered the softening temperature and the increasing borax content also lowered bulk density. When the content of raw materials and the sintering temperature were fixed, bulk density decreased with the increasing foaming agent content. Additionally, sodium phosphate could act as both foam stabilizer and fluxing agent. The optimal content of borax, foaming agent and sodium phosphate is 20 wt. $\%, 1-2$ wt. $\%, 2$ wt. $\%$, respectively. The sample sintered at this optimal condition has the lowest density of $0.7 \mathrm{~g} / \mathrm{cm}^{3}$ and this result was used in following simulation.

Finally, as the result showed in simulation of EnergyPlus, the foam glass obtainded in this research have good energy conservation performance as thermal insulation materials. The energy consumption can be reduced by at most $32.3 \%$ per year. Besides, colder regions have more energy-saving potential to apply this foam glass.

\section{Acknowledgements}

This paper was supported by the National Natural Science Foundation of China (51708022). Supports by The Fundamental Research Funds for the Central Universities (FRF-TP-18-024A2), Student Research Training Program in China, and the program of China Scholarships Council (201806465006) are also acknowledged. 


\section{References}

[1] Jiang Yi, 2017 Annual Report on China Building Energy Efficiency[M].Beijing:2017

[2] Zhang Y , He C Q , Tang B J , et al. Chinal"s energy consumption in the building sector: A life cycle approach[J]. Energy and Buildings, 2015, 94:240-251.

[3] T Baracu T, Badescu V, Teodosiu C, et al. Consideration of a new extended power law of air infiltration through the building's envelope providing estimations of the leakage area[J].Energy and Buildings, 2017,149:400-423.

[4] Iordache V, Nastase I, Damian A, et al. Average permeability measurements for an individual dwelling in Romania[J]. Building \& Environment, 2011, 46(5):1115-1124.

[5] Hammel E C , Ighodaro L R , Okoli O I . Processing and properties of advanced porous ceramics: An application based review[J]. Ceramics International, 2014, 40(10):15351-15370.

[6] Sun Q, Shi D X, Wang W B, et al. Analyses the New Building Wall Materials and Exterior Wall Thermal Insulation Technology[J]. Applied Mechanics \& Materials, 2014, 584-586:1545-1550.

[7] Zhu M, Ru Ji, Li Z, et al. Preparation of glass ceramic foams for thermal insulation applications from coal fly ash and waste glass[J]. Construction \& Building Materials, $2016,112: 398-405$

[8] Ru Ji, Wu S, Yan C, et al. Preparation and Characterization of the One-piece Wall Ceramic Board by Using Solid Wastes[J]. Ceramics International, 2017.12(43):85648571.

[9] Pawel Stoch, Immobilization of hospital waste incineration ashes in glass-ceramic composites[J]. Ceramics International. 2018.44:728-734. 
[10] Taoyong Liu, Phase evolution, pore morphology and microstructure of glass ceramic foams derived from tailings wastes[J]. Ceramics International. 2018.44: 1439314400.

[11] H.R. Fernandes, Preparation and characterization of foams from sheet glass and fly ash using carbonates as foaming agents[J]. Ceramics International. 2009.35:229-235. [12] Olli Vaentsi, Mineral wool waste in Europe: a review of mineral wool waste quantity, quality, and current recycling methods[J]. Mater Cycles Waste Manag. 2014. $16: 62-72$.

[13] Pranckeviceine J, Balkevicius V,Spokauskas AA. Investigation on properties of sintered ceramics out of low-melting illite clay and additive of fine-dispersed nepheline syenite. Medziagotyra. 2010.16:231-235.

[14] J.Yliniemi, Pulverization of fibrous mineral wool waste[J]. Journal of Material Cycles and Waste Management. 2018.20:1248-1256.

[15] R. Stonys, Reuse of ultrafine mineral wool production waste in the manufacture of refractory concrete[J]. Journal of Environmental Management. 2016. 176:149-156.

[16] Feng Shizhang, Waste glass resource utilization technology[M].Beijing: Chemical Industry Press,2015.8

[17] C Silva R V , Brito J D, Lye C Q, et al. The role of glass waste in the production of ceramic-based products and other applications: A review[J]. Journal of Cleaner Production, 2017, 167:346-364.

[18] Lodins, E; Rozenstrauha, et al, Characterization of glass ceramics microstructure, chemical composition and mechanical properties, IOP Conference Series: Materials Science and Engineering, 2011.25(1):012-015. 
[19] Hao Wang, Yongqi Sun, et al, Integrated utilization of fly ash and waste glass for synthesis of foam/dense bi-layered insulation ceramic tile[J]. Energy \& Buildings.2018.168:67-75.

[20] Cuiping Xi, Feng Zheng, et al, Preparation of glass-ceramic foams using extracted titanium tailing and glass waste as raw materials $[\mathrm{J}]$. Construction and Building Materials, 2018.190:896-909.

[21] Hao Wang, Ziwei Chen, et al, Synthesis of a foam ceramic based on ceramic tile polishing waste using $\mathrm{SiC}$ as foaming agent[J]. Ceramics International. 2018.44:1007810086.

[22] Hao Wang, Ziwei Chen, et al. Integrated utilization of high alumina fly ash for synthesis of foam glass ceramic [J]. Ceramics International, 2018.

[23] Baoshan Tang, Jian Lin, et al., Preparation of glass-ceramic foams from the municipal solid waste slag produced by plasma gasification process, Mater. Lett. 2014.128 (10):68-70.

[24] Mi H, Yang J, Su Z, et al. Preparation of ultra-light ceramic foams from waste glass and fly ash[J]. Advances in Applied Ceramics, 2017, 116(7):1-9.

[25] Abbasi S, Mirkazemi S M, Ziaee A, et al. The effects of $\mathrm{Fe}_{2} \mathrm{O}_{3}$, and $\mathrm{Co}_{3} \mathrm{O}_{4}$, on microstructure and properties of foam glass from soda lime waste glasses [J]. Glass Physics \& Chemistry, 2014, 40(2):173-179.

[26] Ru Ji, Zhang Z, et al. Synthesis, characterization and modeling of new building insulation material using ceramic polishing waste residue $[\mathrm{J}]$. Construction \& Building Materials, 2015, 85:119-126.

[27] Wang H, Feng K, Sun Q. Effect of calcium carbonate on the preparation of glass ceramic foams from water-quenched titanium-bearing blast furnace slag and waste glass[J]. Advances in Applied Ceramics, 2018, 117(5):1-7. 
[28] Yuxi Guo, Yihe Zhang, et al. Novel glass ceramic foams materials based on polishing porcelain waste using the carbon ash waste as foaming agent $[\mathrm{J}]$. Construction \& Building Materials, 2016, 125:1093-1100.

[29] Fengjuan Pei, Hongwei Guo,et al, Influence of low magnesia content on the $\mathrm{CaO}$ Al2O3-SiO2 glass-ceramics: Its crystallization behaviour, microstructure and physical properties[J]. Ceramics International. 2018.44(16):20132-20139.

[30] M.Ozabaci, M.A.Aksanb, Preparation and characterization of $\mathrm{CaO}-\mathrm{Al} 2 \mathrm{O} 3-\mathrm{SiO} 2$ (CAS) glass-ceramics[J]. Journal of Non-Crystalline Solids. 2016.454(15):8-12.

[31] Berardi U, Soudian S . Benefits of latent thermal energy storage in the retrofit of Canadian high-rise residential buildings[J]. Building Simulation, 2018, 11(1). 


\section{Table and Figure Captions}

Table 1. The chemical compositions (wt.\%) of raw materials.

Table 2. Raw materials compositions(wt.\%) of samples.

Table 3. Chemical compositions(wt.\%) of samples.

Fig.1. Effects of the content of mineral wool waste on the (a) bulk density,(b) top and side view of green sample S0 and sample S1 S2 S3 S4 S5 at $800^{\circ} \mathrm{C}$.

Fig.2. SEM images of samples S1 S5 sintered at $800{ }^{\circ} \mathrm{C}$.

Fig.3. Effects of sintering temperature on the (a) bulk density, (b) top view of sample S4.

Fig.4. The SEM images of samples ultimately sintered at different temperature: (a) $600{ }^{\circ} \mathrm{C}$, (b) $700{ }^{\circ} \mathrm{C}$, (c) $800{ }^{\circ} \mathrm{C}$, (d) $1000{ }^{\circ} \mathrm{C}$.

Fig.5. XRD analysis of samples S4 sintered at different temperatures.

Fig.6. Effect of borax content on (a) bulk density and (b)top and side views of samples containing $40 \mathrm{wt} . \%$ mineral wool waste(S4) sintered at $800{ }^{\circ} \mathrm{C}$.

Fig.7. Effects of content of foaming agent on the (a) density of sample S4, (b) side views of samples containing $30 \mathrm{wt} . \%$ borax with $1 \mathrm{wt} . \%$ to $3 \mathrm{wt} . \%$ foaming agent sintered at $800^{\circ} \mathrm{C}$.

Fig.8. The effect of $\mathrm{Na}_{3} \mathrm{PO}_{4} \cdot 12 \mathrm{H}_{2} \mathrm{O}$ content on the (a) bulk density,(b) side views of $\mathrm{S} 4$ sintered at $800^{\circ} \mathrm{C}$.

Fig. 9. The building simulation model.

Fig.10. Outdoor air temperature in three climates.

Fig.11. Heating and cooling loads in different climate regions for different exterior walls:

(a) separate district loads and (b) annual loads. 